\title{
Bresser Pereira e a Reforma Gerencial do Estado
}

\section{Bresser Pereira and the State Management Reform}

Entrevista Realizada em 23/03/2016, em São Paulo

Entrevistado: Luiz Carlos Bresser-Pereira, professor da Fundação Getúlio Vargas (FGV-EAESP) e Ex-Ministro da Administração Federal e Reforma do Estado (1995-1998)

Entrevistador: Amon Barros, professor da Fundação Getúlio Vargas (FGV-EAESP)

Texto completo em português: http://www.apgs.ufv.br Full text in Portuguese: http://www.apgs.ufv.br

Amon de Barros [AB]: Boa tarde, professor. Agradeço muito ao senhor por aceitar conceder essa entrevista. Como temos um roteiro pré-preparado, seguirei uma estrutura, o que não impede de modificarmos o que foi proposto. Gostaria de iniciar com a seguinte pergunta: nos diários do ex-presidente Fernando Henrique, menciona-se que o senhor teria interesse de ingressar no novo governo como ministro das relações exteriores, mas que isso teria sido vetado pelo ex-presidente José Sarney e encontrado resistência em quadros do Itamaraty. As citações no diário deixam a entender que a reforma do Estado não fazia parte do projeto político do PSDB. Dessa forma, como o senhor conseguiu reverter isso e dar visibilidade ao projeto de reforma de administração de Estado?

Bresser Pereira [BP]: Eu havia sido tesoureiro da campanha do Fernando Henrique, que já tinha escolhido boa parte dos ministérios e não falava comigo. Afinal, veio conversar e me perguntou qual Ministério eu queria. Respondi que gostaria de ter o Ministério das Relações Exteriores ou a SAF - Secretaria de Administração Pública Federal, dando a ele duas alternativas. Em seguida, houve inclusive uma confusão, porque alguns dias depois apareceu uma manchete da Folha, dizendo que eu tinha sido escolhido Ministro das Relações Exteriores. Infelizmente não foi, porque o Ministério das Relações Exteriores é, sem dúvida, mais importante que o Ministério da Administração Pública Federal. [...] Mas eu não teria tido oportunidade de fazer essa maravilhosa reforma em que eu me vi envolvido. Então, isso foi muito bom. De fato, essa reforma não estava na agenda da campanha do Fernando Henrique, que não tinha nada a respeito disso. Porém, quando eu disse que tinha interesse na SAF é porque tinha ideias, era Professor da EAESP e ensinava regularmente no curso de pós-graduação em educação pública que havia naquela época. Inclusive, tinha algumas orientandas e já havia lido várias coisas sobre administração pública. Por isso, possuía ideias razoavelmente claras e seria possível fazer alguma coisa importante lá. Então, na primeira conversa que tive com Fernando Henrique depois que aceitei o ministério, disse a ele qual era minha ideia e muito sumariamente ele respondeu que aquilo não estava na agenda do governo e não fazia parte das reformas que estávamos prevendo. Mas, Fernando Henrique é uma pessoa muito democrática e muito aberta, não me abandonando, mesmo que as reformas desejadas, naquela época, fossem as tributárias e as previdenciárias - e essas envolviam emendas constitucionais. Eu também possuía uma emenda que queria levar adiante, flexibilizando a estabilidade dos funcionários, dos servidores públicos, e o Fernando Henrique, muito claramente, disse: "vamos ver isso". Depois o Jobim, que era o Ministro da Justiça e era o responsabilizado pelo Fernando Henrique por coordenar um pouco as reformas, me disse: "vamos ver o que e quais os tipos de apoios ele obtém". Outro fato importante foi a minha designação para ser um dos ministros que falava no final de janeiro, primeiro mês, para as bancadas dos diversos partidos que apoiavam o governo. Isso aconteceu na Escola de Administração Fazendária - ESAF - onde fiz minha apresentação, uma vez que tinha uma ideia básica de fazer uma reforma gerencial apoiado naquele momento, ainda, apenas no livro de David Osborne e Ted Glaeber, "Reinventando o governo". Ao falar para os deputados e senadores dos diversos partidos percebi que teria um apoio especialmente dos governadores e de alguns dos grandes prefeitos, até porque aquela reforma fazia todo sentido para eles também. Trabalhei firmemente nessa direção de forma que, ao se passarem três meses, a reforma havia conseguido apoio suficiente para o Fernando Henrique dizer: "está ok, vá em frente e apresente a emenda afinal". Então, foi um grande processo de convencimento, mas acho que o Brasil estava absolutamente maduro para aquilo e que haveria grandes ganhos na reforma, de maneira que eu também estava muito confiante.

[AB] Professor, já que mencionou que os governadores e os prefeitos seriam seus aliados nesse processo, como o senhor analisa as crises de replicação da reforma a nível dos estados e dos municípios, sendo que muitas delas ainda tentam mimetizar aquele processo de 1995, que ainda é o grande modelo, o grande paradigma que muitas vezes é assumido hoje em dia nos projetos de reforma dos estados e municípios?

[BP] Em primeiro lugar, não há outro paradigma. A meu ver, só existem duas reformas historicamente importantes e significativas da administração pública. A administração pública nasce, ou melhor, o Estado Moderno nasce com as monarquias absolutas, e a forma de organização administrativa do Estado é chamada de patrimonialismo. Então, houve a Revolução Industrial e a Revolução Francesa, entrando no período liberal, no século XX. Dessa forma, o patrimonialismo era incompatível com uma economia capitalista liberal e se fez no século dezenove. Nesse, os principais países desenvolvidos fizeram a sua reforma burocrática, chamando-a, do inglês, de civil service reform. Eu a denomino como reforma burocrática ou reforma weberiana. Não que Weber tenha feito a reforma, mas porque ele escreveu sobre e explicou o que era burocracia de uma maneira absolutamente genial. Porém, essa reforma era feita por um Estado liberal, ou seja, um estado que possuía $7 \%$ do PIB em termos de despesas, era um estado muito pequeno. Existem muitas pessoas que acham que o que Weber descobriu na burocracia um sistema eficiente, no entanto, não é isso. O que importava realmente nessas reformas, principalmente para os governantes da época, é que o Estado fosse efetivo, ou seja, que a sua lei valesse, fosse cumprida, que ela fosse, em inglês, enforced, que é uma boa palavra. Significando que a burocracia weberiana, profissional e impessoal, rodada no segredo e etc. tinha esse objetivo. Assim, o tempo passou, o Brasil fez a sua reforma gerencial, reforma burocrática, nos anos $30 \mathrm{com}$ Getúlio Vargas. Aí o tempo passou. Com o decorrer do tempo, no centro do mundo, na Europa, o que aconteceu? O Estado, quase um século depois, quando chegamos nos anos de 1980, não era mais um Estado de $7 \%$ do PIB, mas sim um Estado de $42 \%$ do PIB. Não era mais liberal, e sim um Estado democrático-social, que tinha enormes serviços públicos de educação, saúde, previdência social, assistência social, cultura, esportes, apoio à ciência e tecnologia. Agora, com uma organização muito maior, a eficiência tornava-se uma coisa decisiva. A reforma gerencial - Public Management Reform, o melhor nome para mim é gerencial, sem dúvida - vai atender a isso: por ora o importante - e, veja, é importante dizer não é tornar o gabinete do Ministro da Fazenda ou o departamento 
de política educacional do Ministério da Saúde mais eficiente, isso continua não sendo importante. Agora, é extremamente importante que as escolas, as unidades do INSS e os hospitais sejam eficientes. É por isso que surge a segunda reforma e por ela entende-se que a transição para um Estado de bem-estar social, democrático e social, é inevitável - eu acho que é. Os Estados Unidos, o país que mais resistiu a isso, aos poucos vai se transformando, como o Obama conseguiu fazer agora com o sistema de saúde. Então, a reforma gerencial é inevitável. Ela é a segunda reforma e vai acontecer em todos os países assim que eles se desenvolvam. No entanto, isso pode acontecer mais depressa ou mais devagar. Por exemplo, os países que começaram a reforma foram a Inglaterra, Nova Zelândia e Austrália. E logo em seguida vem o Brasil e o Chile, antes da França e da Alemanha. Mas os outros países ricos também estão todos fazendo a reforma e muitos outros países farão quando eles se virem diante de um problema de administrar grandes unidades de serviços sociais e científicos. Então, em relação aos estados, em relação à pergunta mais específica [...] quer dizer, agora sou governador de Pernambuco ou governador do Amazonas, pouco importa, tenho que governar e aí eu, governador, também tenho vários serviços. Tenho hospitais, escolas, assistência social. Por isso, preciso tornar essa coisa eficiente. No entanto, meu dinheiro é pouco e as demandas que ocorrem sobre mim exigem um sistema para tornar isso mais eficiente. Sendo a reforma uma estratégia de gestão, ela tem dois aspectos: tem um aspecto de gestão e tem um aspecto de estrutura. O aspecto da gestão o que é, essencialmente? É, antes de tudo, colocar em segundo plano a gestão burocrática, por regulamentos rígidos, supervisão cerrada e auditoria, especialmente regulamentos rígidos e supervisão cerrada. Auditoria você precisa continuar a ter, mas ela também precisa se tornar mais leve. Deve-se acrescentar três novas [esferas]: a administração por resultados contratados, a administração por competição administrativa por excelência (não é por lucro, é por excelência, uma vez que não existe lucro no setor público em questão, claro), as quais aprendemos no setor privado, e, por fim, a responsabilização social, vista na ideia da democracia participativa. Isso é a parte gestão. Ora, duas dessas coisas a gente aprendeu no setor privado, a administração por resultados e a competição administrativa. A terceira a gente aprendeu com a democracia, a ideia da democracia participativa. Por outro lado, há o aspecto estrutural, que são as duas instituições básicas da reforma: as agências executivas e, principalmente, as organizações sociais, porque é ali que você vai ter uma mudança muito grande. Lá que acontecerão mudanças muito grandes. $E$ os estados também deveriam fazer a mesma coisa, quer dizer, não há outra alternativa. Qual é a outra teoria? Mas então essa é também a teoria da Nova Gestão Pública (NPM)? É parecida. Em relação à teoria da Nova Gestão Pública - também me inspirei um pouco nela, cito isso em meus trabalhos - acho que o meu sistema teórico é bem melhor que o deles e bem mais geral. E, por outro lado, bem mais aplicado ao Brasil. Se você pegar o meu livro, Construindo o Estado Republicano, na segunda parte tem a Teoria Geral da Reforma. Todo o livro, na verdade, é a Teoria Geral da Reforma. Não conheço nenhum livro da NPM tão bom quanto esse.

[AB]: Quando o plano da reforma foi lançado, e mesmo depois, alguns críticos, como a Christina Andrews, por exemplo, procuraram denunciar as influências do neoinstitucionalismo, da escolha racional e da New Public Management, no que foram prontamente rechaçados naquele momento. Examinando aquelas ideias com distanciamento histórico e a partir de uma autocrítica, se é que podemos chamar assim, que o senhor publicou no Valor Econômico, em 2011, em uma entrevista [...].

[BP]: Autocrítica?

[AB]: Vou ler a passagem por senhor. "Será que a insistência em propostas como a do social-liberalismo, a rejeição do intervencionismo e incorporação da agenda do Consenso de Washington não seriam reveladores da New Public Management?"

[BP]: Não entendi essa frase. Absolutamente. Essa frase é uma frase minha?

[AB]: Não. Vou ler para o senhor. "O senhor está onde sempre esteve?" - pergunta a jornalista do Valor ao senhor. E o senhor responde: "No governo Fernando Henrique, ou nos anos 90, a hegemonia neoliberal foi muito violenta. Foi tão violenta que também atingiu a mim. Não escapei dela. Logo que saí do governo publiquei um livro chamado $A$ crise do Estado. Aí resolvi publicá-lo em inglês e revi o livro todo, de forma que, quatro anos depois, ele foi publicado em inglês. Quando isso aconteceu já estava entusiasmado com a vitória do Fernando Henrique e influenciado pelas ideias liberais. Não tinha me tornado neoliberal, de forma nenhuma, tenho certeza disso, mas estava mais perto do neoliberalismo do eu estou hoje". Então, se o senhor analisa as críticas que recebeu naquele momento, acha que essas propostas, por exemplo, do social-liberalismo, rejeição do intervencionismo e incorporação do Consenso de Washington, como é colocado, é revelador de uma influência neoliberal no senhor? Ou seria no pensamento do momento?

[BP]: Em relação ao Consenso de Washington, creio que fui o primeiro a fazer a crítica, em 1990, na aula magna que eu dei na Anpec, e que foi publicado um artigo na revista de Pesquisa e Planejamento do IPEA, que sempre publicava as aulas magnas do IPEA. Então nunca comprei o Consenso de Washington. A outra coisa é [...] além do social-liberalismo tinha mais alguma coisa [...].

\section{[AB]: Rejeição do intervencionismo.}

[BP]: Eu nunca rejeitei intervencionismo. Sempre fui a favor de um intervencionismo moderado. Intervencionismo radical é o estatismo e sou absolutamente contra isso. Agora, em relação à expressão liberalismo social, o buscava e realmente fiquei muito interessado. Tenho para mim, muito claramente, que o mercado é uma instituição muito importante na coordenação econômica, nas sociedades capitalistas. $E$ essas têm duas instituições fundamentais que a coordenam: um é o Estado e o outro é o mercado. Mas o primeiro é o mais importante, inclusive, porque regula o mercado. Já mercado é a novidade e, para coordenar o setor competitivo da economia, nada o substitui. Esse é, de longe, a melhor instituição, desde que apenas regulada pelo Estado. Agora percebi que, por outro lado, no tipo de proposta que fazia para reforma gerencial havia, por exemplo, a ideia da competição administrada por excelência, que é a comparação de agências semelhantes agindo em setores semelhantes para ver quem está agindo melhor, comparando um com o outro. Estabelecer os parâmetros ou metas não em função da meta que você resolve, mas em função da meta que emerge da competição. $E$ isso era uma forma de liberalismo econômico que eu estava de acordo. Liberalismo econômico no setor competitivo da economia, estou de acordo. E ao mesmo tempo estava estudando muito, desde que eu saí do governo, em dezembro de 1987. Eu passei a estudar muito a Teoria Política e, especificamente, Norberto Bobbio. Fiquei muito interessado pelo Norberto Bobbio, por ele e pelas suas ideias que discutiam sobre o liberalismo social, sobre Carlo Rosselli, que foi o inventor disso e posteriormente assassinado pelos fascistas na Itália. Em 1992 eu fui à Itália, a Turim, para fazer uma entrevista com o Norberto Bobbio sobre o socialismo liberal, que foi publicada na Folha e em na minha página na internet. Então, continuei com essas ideias durante o governo Fernando Henrique, achando então que o social-liberalismo era um avanço em relação à socialdemocracia porque essa insistia muito na parte burocrática, administrativa, em grandes serviços sociais e científicos sob controle do Estado diretamente. Não tinha outra alternativa, não pensaram na organização social. E estava propondo as organizações como algo muito mais próximo do social-liberalismo 
ou socialismo liberal - que expressões equivalentes. E continuei nessa linha. Quando saí do governo, tive um convite para escrever em um livro organizado pelo Anthony Giddens e escrevi várias coisas sobre a terceira via e a social-democracia. E para mim, a social democracia e o social-liberalismo eram quase iguais, só que o último era um avanço, o social-liberalismo era um avanço. Entretanto, com o tempo, cheguei à conclusão que o socialliberalismo tinha sido afinal capturado pela direita e que não valia a pena. A partir de um certo momento, deixei de usar essa expressão social-liberalismo porque o Bobbio não era de direita, as coisas que eu pensava absolutamente não eram de direita, mas a expressão foi ganhando por esse lado. Nunca fiz uma análise concreta sobre isso e talvez esta entrevista seja a coisa mais clara que eu tenha sobre esse assunto. Agora, não sei se você fará uma pergunta sobre isso, mas no início da questão aparece uma indicação: "afinal, essa reforma é uma reforma neoliberal ou não?" Você não fez essa pergunta diretamente, mas quase. $\mathrm{E}$ eu respondo: Em relação a essa reforma ser neoliberal ou não, absolutamente não é uma reforma neoliberal. Não quero discutir New Public Management e também acho que não foi neoliberal lá, quero discutir minha reforma e minha teoria antes da minha reforma. Tenho primeiro uma prova de que ela não é neoliberal, além de eu ser profundamente contra o neoliberalismo por ser uma ideologia regressiva; reacionária e regressiva. O neoliberalismo foi assumido pelo governo Reagan, que encarregou o Banco Mundial pelas reformas. O FMI era responsável pelos ajustes estruturais e o Banco Mundial pelas reformas. O Banco Mundial foi rigorosamente contra a reforma gerencial. Não apenas contra a minha, também contra lá fora, mas esta era outra coisa, eles nem sabiam; eram mal informados. Me lembro muito bem que no Canadá, muitos anos depois, vi uma professora da área de gestão pública dizendo que o Banco Mundial apoiou a reforma gerencial, mas ela estava mal informada. Ela é de esquerda. Sou solidário a ela por ser de esquerda, eu também sou. Mas a desinformação da esquerda às vezes é lastimável. Cheguei no ministério no começo de janeiro de 1995. Quando foi próximo a maio, recebi a visita de cinco ou seis técnicos do Banco Mundial e contei qual era minha reforma. Eles ouviram e foram embora, e fiquei sem saber deles durante três anos. Três anos depois, em 1998, no último ano do meu ministério, eles me convidaram para fazer uma palestra na conferência anual de treinamento interno dos funcionários do Banco que ocorreria ao lado de Washington, na universidade de Mariland. É uma enorme reunião, com mil técnicos e eu era um dos convidados. Fiz um debate feroz contra três técnicos do Banco Mundial que tinham sido escalados para discutir comigo porque eles eram contra a reforma. Qual era o argumento deles? Eram contra por uma questão de sequencing. Eu tinha inclusive resposta padrão para isso. Primeiro vocês querem que terminemos a reforma burocrática e depois, quando tivermos competência para isso, aí sim faríamos a reforma gerencial. Concordo, com uma condição, que também façam a recomendação ao governo brasileiro e talvez ele aceite, de que o Brasil deve primeiro terminar a revolução mecânica e depois realizar a revolução digital. Entende? Lamentável. Eu disse que mesmo em relação à reforma do New Public Management, se não eram contra eles, estavam muito mal informados. Nessa mesma reunião foi convidado o diretor do Next Steps, que é o programa britânico que começou a reforma, e continuava em 1998. Quer dizer, uma coisa que aconteceu em 1987, onze anos depois é que eles iam tomar conhecimento. Pode imaginar, então, que reforma gerencial não tem nada de neoliberal, absolutamente nada. $\mathrm{O}$ que a reforma tem é que ela visa tornar mais eficiente o sistema. Outra crítica que se fazia era que a reforma era contra o servidor público. Isso é uma bobagem enorme. Essa reforma é profundamente a favor dos bons servidores públicos. Estes estão sendo desmoralizados por danos de maus funcionários, que se aproveitam da estabilidade plena que eles têm para trabalhar muito pouco ou nada. E estou certo que vou convencer os bons servidores, porque também na Inglaterra a reforma gerencial aconteceu não porque a Margaret propôs. Isso é importante, a Margaret Tatcher queria reduzir o tamanho do Estado e mais nada, só queria cortar despesa. E aí um grupo de servidores públicos de alto nível dissea ela: "olha, nós ajudamos a senhora a fazer isso se a senhora nos ajudar a fazer essa reforma que nós queremos". Foi então que iniciou o Next Steps e a reforma gerencial, isto é, saindo do próprio serviço público inglês e não de fora. Essencialmente, quer dizer, o que você tem que entender é o seguinte: se você é um social-democrata como eu sou, você acredita que serviços sociais são muito importantes, porque eles são uma forma de diminuir a desigualdade muito eficiente e muito forte. Imagine se nós fizéssemos isso aqui no Brasil e disséssemos: "olha, fica encerrado o SUS, acabou, não tem mais" [...]. Quanto é que nós estamos gastando no SUS? É tantos milhões? Nós distribuímos em forma de bolsas ou salários - o que seria impossível, faz em termos de bolsas para todo mundo. Seria um desastre completo, o padrão de vida da população brasileira iria lá para baixo, cairia muito. Você teria o caos. Serviços sociais iguais, universais, são não só mais eficientes, mas também muito mais justos. Agora, eles nunca são tão eficientes quanto gostaríamos, eles já são por natureza mais eficientes. Por que eu digo isso? E eu digo isso há muito tempo [...] porque você compara, por exemplo, os serviços de saúde dos países mais avançados da Europa França, Alemanha, Inglaterra - e os Estados Unidos. Nesses três países onde a saúde é fundamentalmente pública, custa $11 \%$ do PIB. Nos EUA, onde é privada, custa $17 \%$ do PIB e não atinge todo mundo. Mas, mesmo assim, preciso tornar mais eficiente e no Brasil, certamente, preciso fechar a boca dos conservadores, como gritava o presidente da Associação Comercial do Rio de Janeiro em um debate comigo no Rio de Janeiro em 1995, quando discutíamos o SUS, que estava uma confusão naquela época, pois não havia dinheiro e estava muito mal organizado. Ele dizia: "não ponha dinheiro bom em cima de dinheiro ruim". Essa é uma frase clássica do conservador. Ou seja, não quero pagar imposto, meu bom dinheiro, que eu tanto sofri e consegui, não vou colocá-lo para burocratas o desperdiçarem. Então preciso tornar mais eficiente do que já é e, para isso, é necessária uma reforma gerencial. Então a Reforma Gerencial, que é a condição da legitimidade de um sistema social-democrático, em minha opinião, é o melhor sistema do mundo. É o que legitima o Estado, que tem uma grande carga tributária para financiar esses serviços e possui um número relativamente pequeno de servidores públicos. Porque esses serviços são prestados através de organizações sociais.

[AB]: Já pegando o gancho professor, como o senhor avalia as críticas que o plano de reformas recebeu em relação à publicização dos serviços via organizações sociais? Ou seja, na medida em que - Estado transfere uma parte da execução para organizações sociais ele não perde um pouco da sua própria capacidade de garantir esses mesmos direitos sociais?

[BP]: Absolutamente não. Pelo contrário, acho que essa questão está superada [...]. Vou respondê-la, mas ela está amplamente superada, pois o número de organizações sociais que vêm sendo criadas no Brasil inteiro é muito grande e o PT que, não só foi contra, mas fez uma Ação Direta de Inconstitucionalidade (ADIN), foi derrotado recentemente. Ou seja, até o PT que foi contra, passou também a adotar. Primeiro, inventaram outros nomes, como "Fundação Pública" e, no caso dos hospitais das universidades, inventaram outro nome, mas é a mesma coisa. Então, acho que em termos práticos esse debate está superado e em termos teóricos, veja, o que o Estado quer? O Estado quer o bem público. O que o Estado quer, por exemplo, em relação à saúde? Quer atender a saúde à população do país a um custo baixo, é isso que ele quer. Ele não tem interesse em saber quem será nomeado médico ou diretor. Tudo isso é absolutamente secundário para o Estado. Ele existe para coletar impostos e gastar dinheiro no objetivo de realizar certas políticas públicas como, por exemplo, a de garantir a mais importante política pública que existe em um Estado capitalista, que é um sistema universal de saúde. É isso que tem que fazer. Então, se ele consegue esse objetivo de forma mais eficiente do que fazendo diretamente, é claro que ele deve fazer. Isso é princípio básico da descentralização mais genericamente administrativa. Se 
você estuda Introdução à Administração, toda vez que eu descentralizo, estou delegando autoridade para baixo, e estou perdendo a minha autoridade. Então por que eu não delego? Porque acho que se houver um processo de delegação desse jeito, meu o objetivo, que é tornar a empresa mais lucrativa, ou no governo, que é tornar o sistema de saúde melhor a um preço mais barato, é atingido. Assim, isso é o que me interessa e não esse poderzinho de nomear ou demitir, que é uma coisa meramente burocrática.

[AB]: Para continuar na mesma linha, o senhor analisaria, por exemplo, como a política de distribuição de vouchers para população escolher a sua própria escola e pagar com vouchers, por exemplo, que o Estado garantiria?

[BP]: Sou contra esse sistema, mas a favor de um sistema de organizações sociais para a educação. Para mim, isso tem várias experiências sendo feitas, principalmente na Inglaterra com as Academias e essas outras coisas, independentemente do partido lá. Nos Estados Unidos houve a tentativa de encaminhar um pouco, que desenvolveram bastante no governo Clinton. Para mim está muito claro que para fazer isso no caso da escola, é necessário que seja uma lei muito especial, com uma estrutura bem especial. Há um obstáculo grande, em que os servidores públicos professores são muito contra. Eles são organizados em sindicatos muito fortes e fechados, e isso é muito ruim. E está associado com o fato de que no Brasil, os professores continuam sendo muito mal pagos. Nós temos uma ideia de que nada é mais importante do que ensino, do que ensinar às crianças. Isso é fato. Então, você analisa uma família de classe média, com pais formados em universidades e ganhando um salário correspondente. Eles têm três ou quatro filhos, sendo que um será advogado, o outro administrador, outro médico, e o outro professor de Ensino Fundamental. Dá para pensar nisso? Não. Mas na Suécia e nos países ricos é possível, pois a distribuição de renda é muito melhor, ou seja, a desigualdade é menor e você paga decentemente os professores. Ele ganhará menos de qualquer forma, não ganhará tanto. Também a profissão dele vai ser muito divertida, dar aula para criança é uma maravilha (risos). Então a reforma, na área da educação fundamental, é mais complicada. Porém, acho que sistemas de autonomia das escolas o maior possível é recomendável. Uma coisa pouco visível nesses últimos anos, mas, eu vejo sistematicamente, é que os resultados de educação fundamental de Minas Gerais são sempre melhores que os dos outros estados. E a única explicação que tenho é que lá, há cerca de aproximadamente vinte anos - acho que quando o Mares Guia foi secretário da educação - eles fizeram uma reforma, dando uma autonomia muito grande às escolas. Fizeram conselhos de pais, entre várias coisas muito interessantes e deu muito certo. Esse Mares Guia foi ministro e é um grande educador, mas, também um empresário, hoje, milionário. Então as pessoas não olham direito o que ele foi capaz de fazer, o que é uma bobagem, pois ele fez coisas muito importantes.

[AB]: Retomando a um ponto que o senhor tocou, você disse que o Estado não quer saber, por exemplo, de indicar um médico, indicar um diretor do posto de saúde. Um dos elementos da reforma parece ser, em alguma medida, analisado, o comportamento da burocracia estatal da forma de um estamento, apartado das demandas sociais. Há uma discussão de que com um sistema distinto de cobrança e de controle sobre esses servidores, eles levariam mais a sério o bem público em geral, e não os interesses específicos da burocracia. Como senhor analisaria a ideia de que a reforma do Estado tem um componente político?

\section{[BP]: A reforma gerencial do Estado.}

[AB]: Desculpe-me, a reforma gerencial do Estado tem um componente político importante, ou seja, querendo então reduzir a distância entre o Estado, o servidor do Estado e a sociedade, mas a partir de uma ação que é técnica, mas tem um efeito político também.

[BP]: Houve uma interpretação da reforma gerencial, que era pagar estímulos em dinheiro para os servidores públicos, que não é a minha ideia absolutamente. Em certos casos até pode se justificar, mas isso não é o essencial porque é preciso servidores públicos poucos e bons e que tenham espírito público, tenham o ethos, do serviço público, e que sejam controlados. Que de um lado eles sejam o mais possível integrados na sociedade, eles fazem parte da sociedade, e isso não pode ser uma coisa separada da sociedade. Mas, por outro lado, sejam controlados pela sociedade. Por isso que o controle social é muito importante. É através de mecanismo de comitês, de ONG's que fazem controle social, que fazem a responsabilização social, é para controlar esses servidores. Agora, eu desconheço qualquer sistema que garanta isso. Quer dizer, o sistema burocrático não garante isso. $O$ sistema gerencial pode ajudar, mas não garante. Porque o meu servidor público, primeiro, são todos de nível superior; segundo, no plano federal só haveria com pós-graduação, caso contrário, não entraria. Sou radical. O governo estadual é diferente e o municipal você pode até com menos, mas no plano federal seriam poucos, muito bem pagos e controlados pela própria burocracia pública e controlados pela sociedade. Mais do que isso, o servidor público tende a ser corporativista, é uma desgraça, não tem muito jeito, não tenho mais solução para isso. Eles dizem que sou a favor de avaliação de mérito, mas você monta um sistema de avaliação de mérito e eles destroem o sistema em um minuto. Dão nota dez para todo mundo, ou então, se você cria uma curva normal, em um ano eles dão nota dez para um, e no outro eles compensam dando nota exótica sempre. Mas enfim, não há solução tranquila para isso. Acho que isso depende muito do nível da sociedade. Estava falando agora com um neto de treze anos, e perguntava para ele se ele sabia o que era ser cidadão e cidadania (risos). Foi por acaso, foi agora no almoço. Então, os servidores públicos são cidadãos, as pessoas que são servidas pelos servidores também são cidadãos. Todos têm que saber dos seus direitos e das suas obrigações. Aqui no Brasil tem-se a mania de pensar que cidadão é um portador de direitos, mas, ele é um portador de direitos e de obrigações, não é? Então, o servidor público tem obrigações muito sérias para com a sociedade que ele serve (risos).

[AB]: Seguindo essa linha, o senhor analisaria como a relação entre a reforma $[\ldots]$.

[BP]: A reforma gerencial do aparelho do estado, porque reforma do estado você faz mudando a Constituição, para começar. O Estado é muito maior. O aparelho de organização pública ou administração pública.

[AB]: Ou entre a administração pública gerencial e a democracia, ou seja, como essas duas coisas se relacionam?

[BP]: Acho que países democráticos são necessariamente países que têm um sistema, um amplo sistema de serviços universais. $E$ quando você tem tudo isso, precisa ter uma administração gerencial. O Estado Absoluto, a ele corresponde uma administração pública patrimonialista. A um Estado Liberal, século XIX, corresponde uma administração burocrática ou weberiana, e a um Estado Social e Democrático, democrático e social, corresponde, necessariamente, uma gerencial. Não pode ser outra. Estão casados. Há aqueles que começam a dizer: "não, porque precisa ter uma terceira forma mais social ainda". Isso é brincadeira. Claro que terá governos diferentes. Agora mesmo tenho aqui uma administração gerencial e essa administração está na Inglaterra, por exemplo, em uma certa época na mão do Brown e, em outra época, está na mão do Cameron. Quer dizer, está no partido social democrata e no partido conservador. Então muda um pouco por causa disso, é inevitável. Uma vai ser mais conservadora que a 
outra e os líderes vão tentar empurrar para esse lado ou para aquele lado. Isso é normal, mas, para mim, o que me parece absurdo é ficar discutindo. Acho que foi Christina Andrews quem inventou um terceiro tipo. Dessa forma, têm-se a burocrática, a gerencial e a social. Isso é ridículo. Isso aconteceu agora comigo também. É verdade que eu nunca tinha juntado as duas coisas. Desde que eu saí do governo, venho desenvolvendo todo um sistema teórico novo chamado de novo desenvolvimentismo, que é uma alternativa ao desenvolvimentismo clássico do Prebisch, do Celso Furtado, do Myrdal, dessas pessoas. Eu e um grupo, que já está ficando maior, estamos desenvolvendo uma série de ideias. Aí vem uns engraçadinhos e dizem: "não, em vez de novo desenvolvimentismo nós propomos um desenvolvimentismo social ou socialdesenvolvimentismo". Porém, dizem isso sem nenhuma teoria. Eu tenho todo um sistema, eles só têm uma coisa. Então, dentro do novo desenvolvimentismo conforme você for mais conservador ou mais progressista, e conforme forem as relações de poder que há, você fará mais uma coisa ou outra, mas você tem uma teoria. $E$ a mesma coisa vale para uma teoria que tenho de como é que se organiza e administra o Estado: era a teoria burocrática, agora tem a teoria gerencial. Essas administrações burocrática e gerencial podem ser feitas tanto por um governo mais conservador ou por um partido mais progressista [...]. Isso vai acontecer inevitavelmente, mas eu não posso criticar a administração gerencial dizendo que ela não é suficientemente social, ou o inverso, que não é suficientemente conservadora. Isso é bobagem porque fica por conta dos governantes no aqui e agora.

[AB]: Em relação à fala que diz respeito ao trabalho nessa proposta do que seria esse novo desenvolvimentismo, o senhor acha ou concordaria que vivemos, talvez no mundo, mas pensando no Brasil, um repique do neoliberalismo? E como isso se relacionaria com essa proposta de um novo desenvolvimentismo?

[BP]: Então, na verdade é uma coisa muito rápida. O Brasil fez sua revolução capitalista, ou fez sua revolução nacional e industrial, incompleta revolução capitalista de um país entre 1930 e 1980. O grande estadista que o Brasil teve no século XX foi Getúlio Vargas, que desencadeou e liderou inicialmente esse processo. $E$ quando nós chegamos em 1980, o Brasil era um país perfeitamente maduro para a democracia, o que não era em 1930. Era um país com uma grande classe de empresários, uma grande classe média, uma grande classe trabalhadora, e nós fizemos a transição democrática. Essa grande revolução capitalista foi realizada integralmente dentro de um sistema econômico desenvolvimentista. O nome que davam era nacional-desenvolvimentismo. Sendo que isso não é uma teoria, e sim a forma prática de fazer. A teoria que o ajudava é o desenvolvimentismo clássico ou estruturalismo latino-americano. No entanto, esse sistema entrou numa grande crise econômica, no começo dos anos 80 , que acabou também sendo política. E a partir de 1985 nós temos a transição democrática, onde os militares também foram desenvolvimentistas. E aí então o que nós vamos ter? Nós vamos ter uma breve experiência desenvolvimentista, na primeira metade do governo Sarney, que é um desastre no Plano Cruzado. E aí depois nós vamos ter uma breve experiência neoliberal, que é o Maílson da Nóbrega no governo, nos dois últimos anos do governo Sarney, que é um desastre tão grande quanto, estando o Brasil com alta inflação, cerca de $15 \%$ ao mês, mais ou menos. Quando chega em fevereiro de 1990, final do governo Sarney, a inflação está em $80 \%$ ao mês, ou seja, hiperinflação. Tecnicamente, acima de $50 \%$ ao mês é hiperinflação. Então temos a partir de 1990 até 2002, por doze anos o regime. Pela primeira vez o Brasil é governado, desde 1930, por liberais, e o liberalismo fracassa. Houve um grande sucesso que foi o fim da inflação, mas, através de um plano heterodoxo que nada tem a ver com o liberalismo econômico que foi usado a partir da teoria da inflação inercial que ajudei a desenvolver. Depois houve um bom interregno do Itamar Franco. Os resultados foram lamentáveis, devido ao crescimento muito baixo, uma grande crise financeira em 1998 e outra em 2002. Posteriormente, vieram então Lula e Dilma, e os resultados novamente foram lamentáveis, e agora desenvolvimentistas. Esses sim eu posso chamar de desenvolvimentistas sociais, mais sociais do que desenvolvimentistas, porque nesses governos, nesses doze anos iniciais, logrou-se uma boa diminuição da desigualdade, o que foi ótimo. Entretanto, crescimento nada. Houve só quatro ou cinco anos no governo Lula, que graças a um boom de commodities a situação melhorou. E aí o Brasil, o Cristo Redentor, virou um foguete que subia para o céu'. Ou seja, nós estamos fracassando. O Brasil é um país que foi um imenso sucesso entre 1930 e 1980, o que mais cresceu no mundo em termos brutos e per capita, ficando atrás somente do Japão. Porém, hoje, é um dos países que menos cresce no mundo, cresce a $1 \%$. Nós crescíamos $4 \%$ per capita. Nós estamos fracassando, seja quando somos desenvolvimentistas ou quando somos liberais. O interessante é que, para acabarmos com a alta inflação que nós tivemos, de 1980 a 1994, foi preciso desenvolver uma teoria nova que a explicasse, que é a teoria da inflação inercial e foi aplicando essa teoria, que tentou-se também aplicá-la no Plano Cruzado e no Plano Bresser, não sendo suficiente. Agora nós temos uma semi-estagnação, crescimento de $1 \%$ há trinta e cinco anos, e pelo menos desde $1994 \mathrm{com}$ as mesmas causas. Uma taxa de câmbio apreciada no longo prazo, só depreciando-se nas crises, como agora, e uma taxa de juros muito alta. Isso inviabiliza o investimento privado e, portanto, inviabiliza também o desenvolvimento econômico. Para enfrentar esse problema é preciso uma teoria nova, que é o novo desenvolvimentismo. É a teoria que explica porque a taxa de câmbio é assim, porque essa taxa tem uma tendência a sobreapreciação cíclica e crônica, e no longo prazo. Cíclica significa dizer vindo de crise em crise, e explica quais são as causas disso e como a neutraliza, enquanto nós não resolvermos como nação. Agora acontece o seguinte: continuo desenvolvendo minhas teorias, nunca desistindo, fazendo com que elas estejam indo bem. Agora sairá um livro bem organizado sobre isso, aqui no Brasil, chamado Macroeconomia Desenvolvimentista pela Campus. Então qual é o obstáculo fundamental a isso? São os dois obstáculos são culturais. Um, é uma alta preferência pelo consumo imediato. É isso que resulta no populismo fiscal, que já é de conhecimento, pois os jornais, os neoliberais não param de afirmar - e eles tem razão quando eles brigam contra déficits públicos crônicos e altos. No curto prazo é bom para consumo. Entretanto, tem um que é pior do que esse, pois se olhar bem, o Brasil, nos doze primeiros anos do governo PT, durante certamente dez, talvez também no décimo primeiro, estava com o ajuste fiscal estava certo e não haviam críticas. Só no último ano que a Dilma perdeu a cabeça e fez as desonerações. Já no segundo populismo, que é o populismo cambial, você deixa a taxa de câmbio apreciada no longo prazo, elevando os salários, os rendimentos de juros, os rendimentos de aluguéis e os rendimentos de dividendos. Todos ficam mais ricos, todos vão para Miami - eu ia para Paris, que era melhor. Ou seja, é um consumo danado e você não cresce. Aí os desenvolvimentistas têm uma vantagem sobre os liberais. Os desenvolvimentistas fazem isso com a consciência pesada, enquanto os liberais fazem isso com a consciência limpa, por dizerem que esses déficits de conta corrente altos, que permitem a taxa de câmbio apreciada - sem déficit de conta corrente alto não tem taxa de câmbio apreciada - são poupança externa. Isso é uma maravilha para o Brasil, pois as multinacionais vêm para cá e ocupam nosso mercado, levando montes de dinheiro para lá e não contribuindo em nada para o desenvolvimento econômico, pois contribuem para o consumo e não para investimento.

[AB]: Já encaminhando para as últimas duas questões, o senhor acha então que, nesse contexto em que vivemos, talvez de crise, desse momento conjuntural, desse momento específico histórico, temos alguma forma, um impulso para voltarmos a falar de reformas 
administrativas no Estado? Seria um novo momento de a gente pensar a gestão do Estado? E no que isso pode ser positivo de alguma maneira?

[BP]: Como temos uma crise muito grande, estávamos estagnados a $1 \%$, agora estamos decrescendo $3,8 \%$ no ano. E esse ano deve ser, dizem os economistas, de $3,2 \%{ }^{2}$. Porém, acho que será menos de $3 \%$, mas muito menos. De forma que, com isso, não sairemos muito dessa crise. E quando nós sairmos dela, uma das coisas que precisam ficar claras para todos nós é que a administração pública é uma área de governo fundamental. Eu, no começo de 1998, como tinha um ministério muito pequeno que transformei em um Think Tank, em um grande divertimento por causa de muitas ideias, uma gama de debates o tempo todo, eu não tinha poder para implementar a reforma. Quem possuía esse poder era o Ministério do Planejamento. Eu tinha visto isso no Chile e nos Estados Unidos. Ainda me lembro bem do correspondente ao ministro da administração pública, um nível abaixo, com quem tive uma entrevista. Ele me disse assim: "Na minha posição tem uma coisa fundamental; olhe quem está do meu lado". Era só uma paredinha, era o diretor do orçamento, um homem poderosíssimo no Estados Unidos. "Eu e ele estamos aqui administrando juntos, o poder está com ele". Então eu resolvi propor ao Fernando Henrique e ao Clóvis Carvalho, que era o Ministro da Casa Civil, que o MARE (Ministério da Administração Federal e Reforma do Estado) fosse reintegrado ao Ministério do Planejamento, como tinha sido no tempo dos militares. Hoje acho que isso foi um erro. Por quê? Porque ao ir para o Ministério do Planejamento ele perdeu importância. Os ministros nunca olharam para ele, somente os secretários executivos de vez em quando olharam, ficando por conta de um secretário modesto da gestão pública. Vi isso quando participei das reuniões da terceira via - depois que saí do governo, o Fernando Henrique me convidou para ser seu secretário para assuntos de terceira via. Participei de três reuniões de terceira via, que foram interessantes, porque os assessores estabeleciam a agenda da próxima reunião, e o que eu via, é que eles sempre defendiam uns cinco ou seis pontos e dentre estes, havia sempre a administração pública, por ser fundamental e dar votos, uma vez que precisavam ser reeleitos. Então, no Brasil acho muito importante que os políticos entendam que a administração pública faz uma diferença, dá votos e que, portanto, eles têm que dar uma prioridade a isso. Sendo este, um assunto de prioridade e, saindo da crise, espero que isso aconteça no Brasil.

[AB]: Por último, citando Jacques Rancière que disse que os ricos odeiam a democracia e que para eles o modo de desmoralizar a democracia é desmoralizar os políticos. Temos vivido um momento em que isso está se verificando amplamente, a chamada classe política passa por um descrédito profundo e é hostilizada pela população de um modo geral. Então, para encerrar, o senhor pode nos oferecer algum tipo de prognóstico sobre a atual crise política? Embora nós não sejamos um jornal...

[BP] Então, entendo que o impeachment que está sendo discutido é um golpe de Estado ${ }^{3}$. Esse mesmo impeachment, de acordo com a constituição brasileira, só é legítimo quando o presidente comete um crime, crime de responsabilidade, o que não aconteceu. Vejo as pessoas mais animadas com o impeachment dizerem: "Depois, quando o Temer for presidente, aí sim será uma maravilha por causa disso e daquilo". Mas, não acho que será maravilha nenhuma e que não haverá impeachment. Continuo mesmo acreditando que não vai haver impeachment, acho que esse raciocínio não é legítimo. E se houvesse uma eleição e fosse Dilma versus Temer, os dois como candidatos, teria que fazer uma previsão de qual será o melhor candidato e votar neste. Mas não agora, pois tenho um presidente já eleito, com todas as normas jurídicas e etc. E se eu o derrubo porque acho que o Temer será melhor, sendo isso inaceitável, absolutamente inconstitucional, uma violência contra a democracia. Agora, por outro lado tenho dito sempre que o Brasil possui uma democracia consolidada. Todos os países que se tornaram democráticos, suas democracias se consolidaram só depois que eles fizeram a sua revolução capitalista. Quando países como o Paraguai fazem revoluções, se tornam democracias antes, sendo essas muito instáveis. O Brasil fez a sua transição para a democracia em 1985, a revolução capitalista estava terminada e, portanto, meu entendimento é que a democracia se tornou consolidada. Se a democracia está consolidada, isso significa que a democracia é entendida como o melhor regime para todos. $E$ todos, quer dizer, todas as classes. Ainda que possa haver, e sempre há, conflitos de classes, todas as classes percebem que, afinal, esse é o melhor sistema que melhor thes garante. Se assim prevalecer, quando se votar na câmara dos deputados, o impeachment. Essa radicalização que aconteceu no Brasil, por parte de grupos de classe média, que de repente esqueceram a política, se encheram de ódio e pela primeira vez na história, pelo menos da república brasileira, pela primeira vez na história do Brasil que eu conheço, com meus 81 anos, vi o ódio como elemento fundamental da política. Nunca tinha visto isso antes. Em 1964, por exemplo, não tinha isso. Havia era medo de uma revolução socialista, a classe média tinha medo, mas não ódio. Agora não, agora tem ódio. E quando se tem ódio, a razão desaparece. E essa semana eu fui a uma bela conferência, da Maria Rita Kehl, em uma escola de classe média alta, chamada Gracinha. Lá foi feita a conferência e depois os debates, e ouvi todos. As pessoas que debateram, toda a classe média alta, adotaram posições muito abertas. Então me senti novamente nos anos 80. De forma que, tenho a impressão que a resistência ao golpe de Estado que está sendo montado por uma direita oportunista, puramente oportunista, vai acabar falhando.

\footnotetext{
${ }^{2} \mathrm{Na}$ entrevista realizada em 23/03/2016, Bresser Pereira destacou a previsão de queda no PIB para aquele ano em $3,2 \%$. Todavia, essa queda foi mais acentuada, fechando 2016 em $-3,6 \%$.
}

\footnotetext{
${ }^{3}$ Bresser Pereira aborda o impeachment da então presidenta Dilma Rousseff, em curso à época da entrevista.
} 